Historic, Archive Document

Do not assume content reflects current scientific knowledge, policies, or practices. 



\section{WHOLESALE LIST}

Austin Originations

No Collection Complete Without

These Beautiful Varieties

A. 珀. Austint $\mathfrak{C}$.

HOME OF ELM HILL GLADIOLI

WAYLAND, OHIO

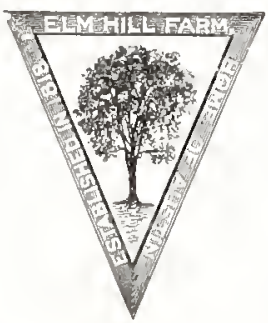

$\mathfrak{J}^{\top}$

WAS OVER A QUARTER OF A century ago that the first Gladiolus bloomed for us and won first place in our hearts. More and more came, and in company with Mother Nature work among them became enchantment. We dreamed of send. ing them into the world that others might revel in their beauty, but the Elms whispered "Wait". Years rolled on and magic came to rule our garden. Long, siender, graceful stems displaced short, stiff spikes (spikes is not a pretty word to be the bearer of beauty). Through years of waiting and the intricate processes of hybridization and selection, giant new and beautiful forms and marvelous colorings were ours, and we knew that the dream could come true. Our belief is firm that the tallest and most graceful Gladioli in existence have been produced, and now we are offering them to you from their HOME AT ELM HILL. 


\section{A. 建. Allstiu $\mathfrak{C} \mathfrak{0}$.}

\section{THE BIG 4-EVELYN KIRTLAND, BERTREX, GRETCHEN ZANG AND HERADA}

Their superiority has been proven by winning numerous First Prizes and Silver Cups at leading exhibitions

\section{EVELYN KIRTLAND}

(Mrs. Austin)

It is difficult to describe in words the beauty of this variety. The flowers of strong substance, are a beautiful shade of rosy pink, darker at the edges, fading to shell pink at the center, with brilliant scarlet blotches on lower petals. Entire flower showing a glistening, sparkling lustre. The form is wide open, somewhat reflexed, slightly fluted and many open at one time. Spike is very tall, straight but slender and bending gracefully with its burden of blooms. Wonderfully decorative.

Read these words of praise from Mr. A. M. Pudor, wholesale and retail florist and properietor of The Pudor Floral Farms, Puyallup, Washington:

"The writer well remembers the day he cut the first Evelyn Kirtland and exclaimed "What a beaurifu thing you are', and GRETCHEN ZANG IS NOT BEHIND. We think it most remarkable for the small sized bulbs we bought of Evelyn Kirtland and Gretchen Zang to produce such wonderful flower spikes, indeed they were tall enough and the blooms large enough to suit our most exacting retail florist customer."

A Prize Winner wherever shown.

\section{$\$ 9.00$ per 100 BERTREX}

(Mrs. Austin)

Stands right at the top of all existing white varieties. Flowers of great substance and of the size and form of America. Increases rapidly, takes up water well and a good shipper. Our customers give their unqualified endorsement. A cup winner.

Read this one: "Of twenty new varieties tried the past season Bertrex was the best for cut flowers, even excelling America, the old standard."-Henry C. Eckert, - _- _, III.

$$
\$ 8.00 \text { per } 100
$$

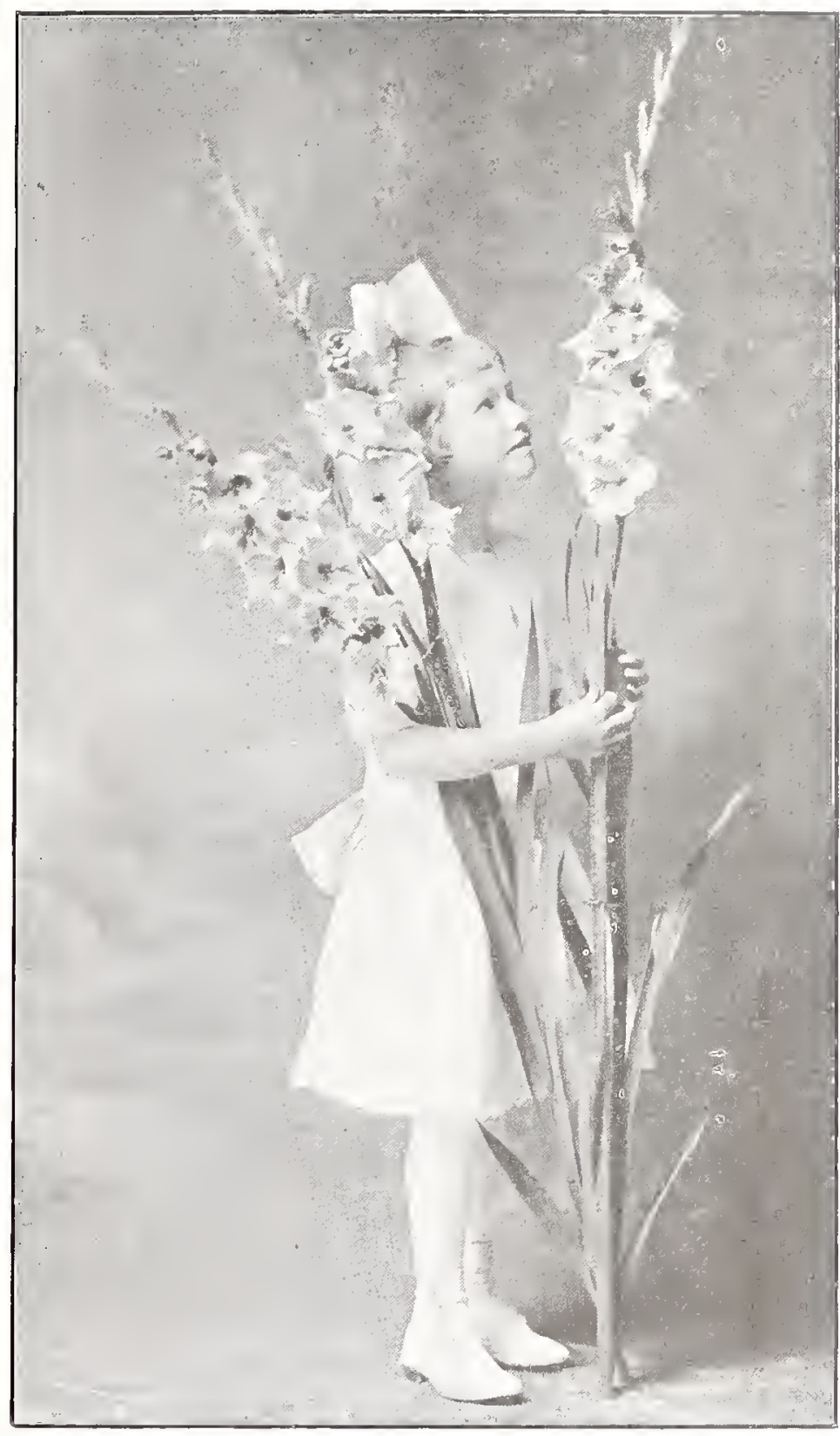

Miss Evelyn Kirtland measuring length of spike (note yard stick) of the Gladiolus named for her. The one she is measuring was cut close to the ground. Three buds are off the top in the illustration. The other spikes were cut leaving four leaves for foliage.

\section{GRETCHEN ZANG}

(Mrs. Austin)

A fitting companion to the Evelyn Kirtland. Large heavy sparkling blooms, a beautiful soft melting shade of pink blending into scarlet on lower petals. Spike tall and graceful. Blooms from small bulbs.

A First Prize Winner and Award of Merit from Gladiolus Sociery of Ohio.

"The bulbs of Gretchen Zang from you did beautifully. It is the most pleasing shade of pink I have ever seen in a "Glad." The florists were very eager for me to grow them in large numbers." E. T. Wig. gington, Louisville, $\mathrm{Ky}$.

"I have Gretchen Zang and like it. The color is soft and restful, more so than the Kirtiand, I think."

C. Cooke, Gladiolus Grower, ____ , Ohio $\$ 6.00$ per 100

\section{HERADA}

(Mrs. Austin)

A new variety and a new color in G'adioli. Biooms of immense size on tall straight spikes. Mas sive in every way. The blooms are pure mauve glistening and clear. Unusually striking and attractive

Winner of First Prize, "Size of Bloom and Spike Only to Count." Also winner in "Best Display New Seedlings." Award of Merit Gladiolus Sociery of Ohio.

"A new touch of color was added to our garden last summer by the introduction of Herada, a brillian mauve that is bound to become popular."-Montague Chamberlain in Garden Magazine.

$$
\$ 8.00 \text { per } 100
$$

PLANTING STOCK - One-half to One Inch Diameter, One-half Above Prices.

SMALL PLANTING STOCK_One-fourth to One-half Inch-Eveyln Kirtland \$22.50 per 1000; Gretchen Zang \$15.00 per 1000 ;

Bertrex and Herada, each at $\$ 20.00$ per 1000 .

25 at 100 Rates. Write for Discount on 1000 or more. All quotáions subject to prior sale 


\section{ADDITIONAL}

\section{AUSTIN ORIGINATIONS}

\section{ROSE WELLS}

Large, wide open flowers; clear pale rose with small attractive blotch of lilac-rose touched yellow. Spike similar and nearly as tall as Evelyn Kirtland. A worthy variety in every way. Prize Winner in Display New Seedlings, Cleveland, 1915 . $\$ 4.00$ per 100

"If I could have but two varieties from your field I would choose Evelyn Kirtland and Rose Wells."-E. Colwell, Steubenville, Ohio.

\section{WHITE CLUSTER}

Large blooms of remarkable substance, opening nearly flat. Pure white with rouch of rose deep in throat. Valuable for florists' design work because of

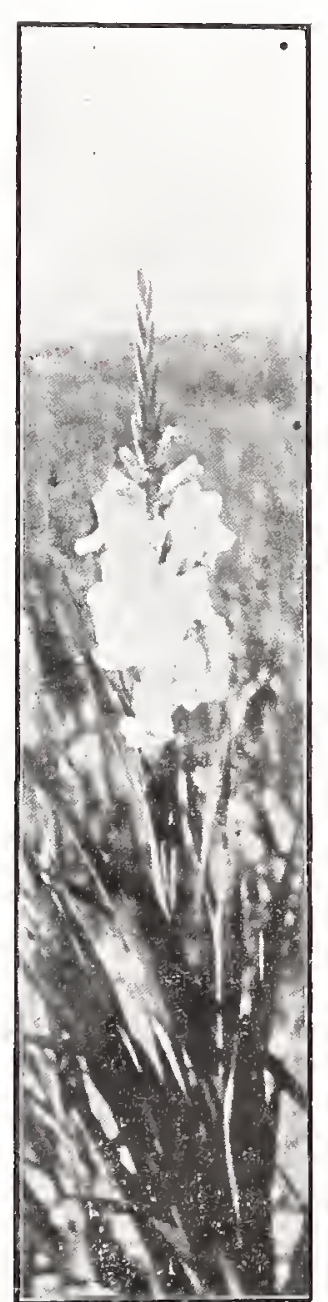

FIELD SPIKE OF BERTREX

\section{A. 预. Austin $\mathfrak{C}$.}

WAYLAND, OHIO

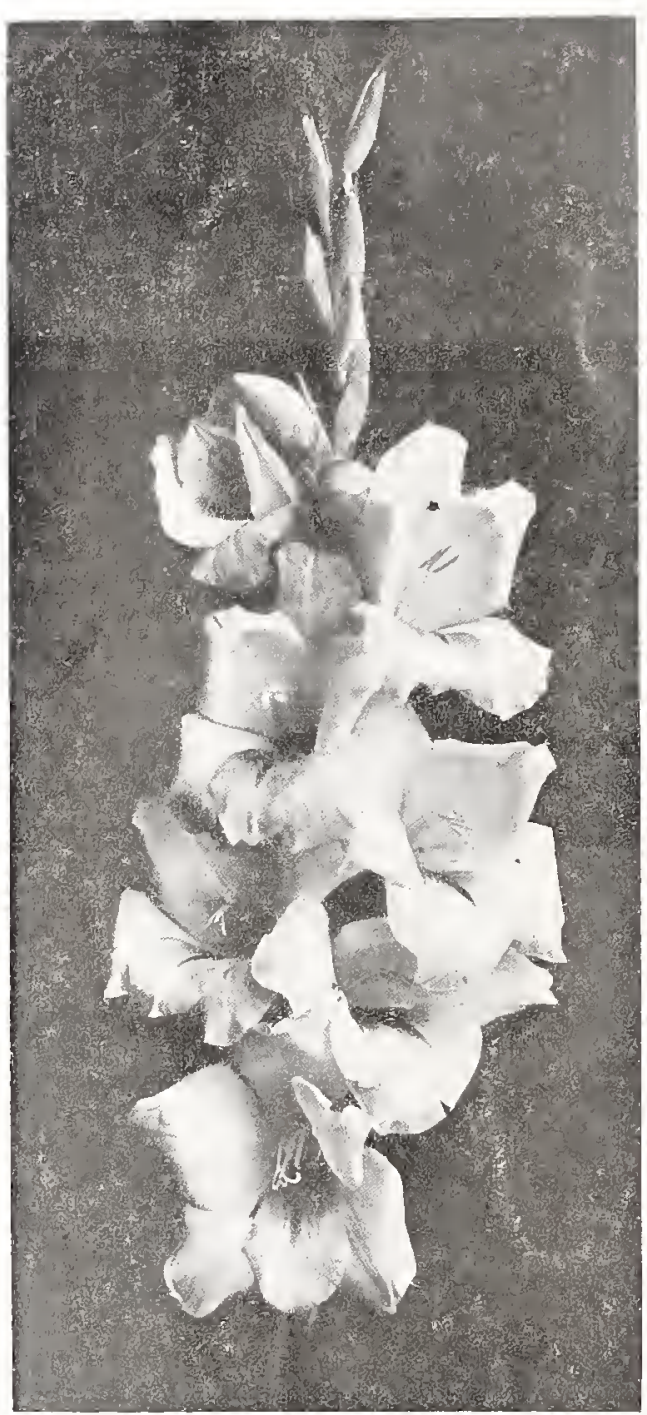

GRETCHEN ZANG

Buy it liberally-it's a winner and a comer.

James F. Rychlik, Florist and Grower, Painesville, Ohio, writes: "Please inform me if you can let me have 2,500 GRETCHEN ZANG. I had spikes of Gretchen Zang over five feet in height and with from eighteen to twenty-six blossoms."
WHOLESALE LIST

\section{Austin Originations}

No Collection Complete Without

These Beautiful Varieties

\section{A. 遑. Austir $\mathfrak{C o}$.}

HOME OF ELM HILL GLADIOLI

\section{WAYLAND, OHIO}

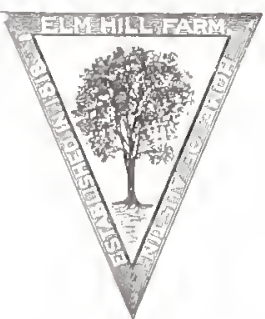

$\mathfrak{I}^{1}$

WAS OVER A QUARTER OF A century ago that the first Gladiolus

bloomed for us and won first place in our hearts. More and more came, and in company with Mother Nature work among them became enchantment. We dreamed of sending them into the world that others might revel in their beauty, but the Elms whispered "Wait". Years rolled on and magic came to rule our garden. Long, slender, graceful stems displaced short, stiff spikes (spikes is not a prerty word to be the bearer of beauty). Through years of waiting and the intricate processes of hybridization and selection, giant new and beautiful forms and marvelous colorings were ours, and we knew that the dream could come true. Our belief is firm that the tallest and most graceful Gladioli in existence have been produced, and now we are offering them to you from their HOME AT ELM HILL. flower slightly open white lavender on lower peral.
$\$ 1.50$

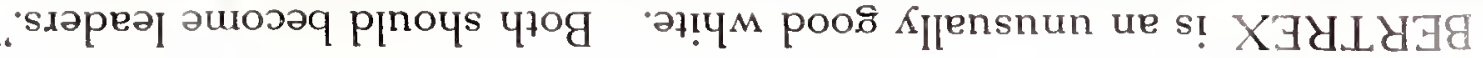

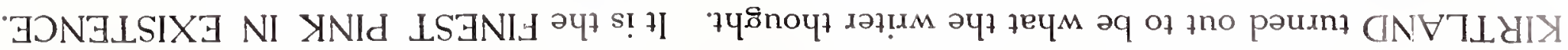

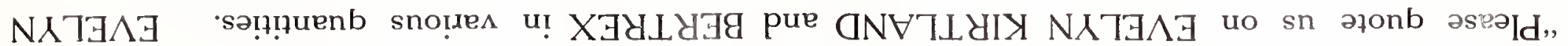

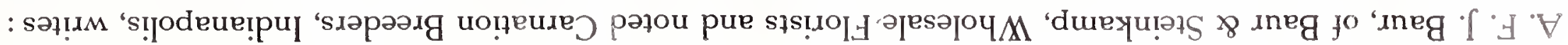

: INGWJSYOCN'J LNVIUOdWI 


\section{Trade List of Gladiolus Bulbs}

GROWN BY

A. H. AUSTIN CO., WAYLAND. OHIO

PER 100

America

First Second Third Bulblets

Delicate pink

Mrs. Francis King _._. $\ldots 2.00 \quad 1.50 \quad 1.00 \quad .50$

Flame color

$\$ 2.25 \$ 1.75 \$ 1.25 \$ \quad .50$

Augusta

Florists' white

Mrs. Frank Pendelton Jr. $6.00 \quad 4.50 \quad 3.00 \quad 1.50$

Bright pink,carmine blotch

Willy Wigman _....... 3.50

White, crimson blotch

Niagara

Soft yellow

Baron Hulot

$\begin{array}{llll}4.00 & 3.50 & 2.50 & 1.00\end{array}$

Best blue

$\begin{array}{llll}2.50 & 2.00 & 1.50 & 1.00\end{array}$

Canary Bird

Deep yellow

$\begin{array}{llll}6.00 & 5.00 \quad 4.00 \quad 4.00\end{array}$

K. Glo:y

(Ruffled) cream

Peace

A grand white

$\begin{array}{llll}5.00 & 4.00 & 3.00 & 3.00\end{array}$

$\begin{array}{llll}3.50 & 2.50 & 2.00 & 2.00\end{array}$

Princeps

Amaryllis flowered

Halley

Salmon pink, early

Prince of Wales

Delicate apricot color, early

Golden King .

Large yellow

Ida Van

Bright cerise

Mrs. W. E. Fryer

Striking red

Myrtle

Arbutus pink

Panama

Large rose pink

$\begin{array}{llll}3.50 & 2.50 & 2.00 & 2.00\end{array}$

$\begin{array}{llll}2.50 & 1.75 & 1.00 & 1.00\end{array}$

Pink Perfection

Very large

$7.50 \quad 5.00$

Empress of India

Very dark red

Schwaben

Very large light yellow

Primulinus Hybrids

$\begin{array}{llll}4.00 & 3.00 & 2.00 & 1.00\end{array}$

All Color Mixture

3.00

2.50

$2.00 \quad 1.00$

Extra choice

Yellow Mixture

High grade

25 at 100 rates; 1000 lots $10 \%$ discount.

First size $1 \frac{1}{2}$ inches up; second $1 \frac{1}{4}$ to $1 \frac{\mathrm{T}}{2}$ inches; third 1 to $1 \frac{1}{4}$ inches. 


\section{A. 湟. Austin $\mathbb{C}$. WAYLAND, OHIO}

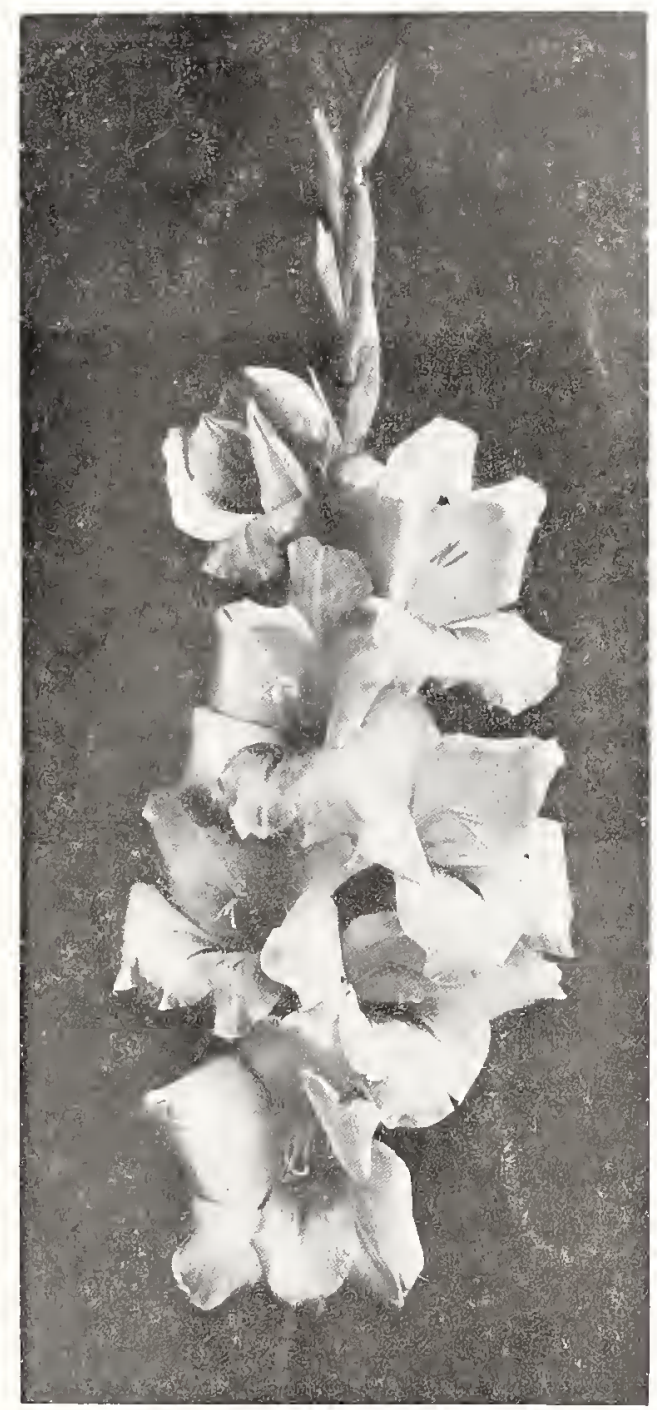

\section{GRETCHEN ZANG}

Buy it liberally-it's a winner and a comer.

James F. Rychlik, Florist and Grower, Painesville, Ohio, writes: "Please inform me if you can let me have 2,500 GRETCHEN ZANG. I had spikes of Gretchen Zang over five feet in height and with from eighteen to twenty-six blossoms." 